\title{
Translation Teaching: The Importance of the Translator's Native Language
}

\author{
Lih-Lirng Soang \\ Tamkang University, Taiwan \\ Email: Ilsoang@mail.tku.edu.tw
}

Received 14 June 2016; accepted 16 July 2016; published 19 July 2016

Copyright (C) 2016 by author and Scientific Research Publishing Inc.

This work is licensed under the Creative Commons Attribution International License (CC BY). http://creativecommons.org/licenses/by/4.0/

cC) (7) Open Access

\begin{abstract}
In the process of translation, student translators often neglect the importance of the knowledge of their mother tongue. When selecting the appropriate vocabulary, students tend to use colloquial language for a written text. They also often ignore cultural factors that would make their translations inappropriate. A new model of teaching, inspired by Bassnett's (2002) analysis of alcoholic beverage advertisements was designed for students to practise in class. Students evaluated their translation process by using a multidisciplinary method proposed by Newmark (1988). Students learn to recognize how translation works by using effective strategies to solve translation problems. This study investigated the problems faced by Taiwanese students when translating a text from Spanish to Chinese in a junior-year translation course at the B1 level at Tamkang University.
\end{abstract}

\section{Keywords}

Translation Teaching, Translation Studies, Translation Method, Advertisement Translation, Mother Tongue

\section{Introduction}

In Taiwan, most research on translation has focused on comparative studies among texts or an individual author's commentary on his/her own translations. Little is known about the methodological problems in teaching, especially in the area of translation between Spanish and Chinese. In fact, the investigation of teaching methods is an urgent issue; the results of such an investigation would contribute greatly to the teaching of translation for not only teachers, but also Taiwanese students as apprentices of the Spanish language.

This study first discusses the fact that students often ignore the importance of the knowledge of their mother tongue, and then examines how a new model of teaching can help students to analyze and evaluate their translation process by using a multidisciplinary approach proposed by Peter Newmark (1988). This new model of teaching 
was inspired by Susan Bassnett's (2002) analysis of alcoholic beverage advertisements, which will be explained in a later part of this paper. Students face translation problems not only linguistically, but also culturally. At the end of the class discussion, students learned to recognize how translation works by using effective strategies to solve translation problems.

The traditional method of teaching translation involves the teacher giving students articles to read. The teacher would then ask students to conduct the translation either orally in class or as a take-home assignment. The result is that many students would tend to rely excessively on the teacher's version rather than on trusting in their own work. Student translators often make mistakes when translating and therefore they are not very highly motivated to learn. They would regard the teacher's version as the gold standard and try to memorize it as much as possible for the sake of exams. In order to call attention to their style of thinking as well as that of writing, it would be necessary to provide students with a new model of practising translation. The purpose of designing a new task-oriented activity would be to guide students step-by-step to think and evaluate their translation process by employing all the strategies that they have learned in class.

Oral Interpretation and Translation (I) is a junior-year course with a total of 72 teaching hours at the B1 level. Each semester has 18 weeks, and there is a two-hour class each week. In the twelfth week of the first semester of 2014, I selected an advertisement about whisky in Spanish for the students to translate for practice. The text was required to be short in length so that the translation work could be completed within the two-hour class. Students are divided into four groups of four or five, and are asked to translate the advertisement into Chinese. After completing the task, they evaluated both their own and other students' translations.

\section{Translation Methods}

Newmark's (1988) theory is recommended by Rosa Rabadán in the initial stage of theorizing translation. According to Rabadán, Newmark is most famous for his theory, which is an approach that comprises both practical and academic areas (Rabadán, 2005: pp. 23-24). According to Newmark, there are eight useful translation methods for the teaching of translation. The first category of translation methods focuses on the source language (SL): 1) word-to-word translation, 2) literal translation, 3) faithful translation, 4) semantic translation. The second category of translation methods focuses on the target language (TL): 5) adaptation, 6) free translation, 7) idiomatic translation, 8) communicative translation (Newmark, 1988: pp. 45-47). Newmark suggests that only semantic and communicative translation would fulfill the two main aims of translation: accuracy and economy. Generally, a semantic translation is written at the author's linguistic level and a communicative translation at the reader's communicative level (Newmark, 1988: p. 47).

Commenting on equivalence and equivalent effect, Jeremy Munday (2001) points out that the description of communicative translation is similar to Nida's (1964) dynamic equivalence in the effect it is trying to create on the TL reader, while semantic translation resembles Nida's formal equivalence. Nevertheless, Newmark distances himself from the full principle of equivalent effect (Munday, 2001: p. 44). Nida's formal equivalence "focuses attention on the message itself, in both form and content” (Nida, 1964: p. 159). And his dynamic equivalence is based on "the principle of equivalent effect", where "the relationship between receptor and message should be substantially the same as that which existed between the original receptors and the message" (Nida, 1964: p. 159).

To continue the discussion of the problems of equivalence, Bassnett (2002, p. 29) argues that "Exact translation is impossible", and prefers Neubert's (1967) theory of "process and product" (32). According to Bassnett, Neubert's theory of translation equivalence is considered a semiotic category that comprises three components: the syntactic, the semantic, and the pragmatic. Among these, the semantic component is the most important: "Equivalence overall results from the relation between signs themselves, the relationship between signs and what they stand for, and the relationship between signs, what they stand for and those who use them" (Bassnett, 2002: p. 34). This study of "signs" or the semiotics is of great value for future research in the translation between Spanish and Chinese. Although Bassnett's (2002) analysis mainly addresses the use of English, the concept of decoding and recoding is applicable in the use of Chinese. It is worth paying attention to what she suggests to the translator who must:

1) Accept the untranslatability of the SL phrase in the TL [at] the linguistic level.

2) Accept the lack of a similar cultural convention in the TL.

3) Consider the range of TL phrases available, [with regards] to the presentation of class, status, age, sex of the speaker, his relationship to the listeners and the context of their meeting in the SL.

4) Consider the significance of the phrase in its particular context-i.e. as a moment of high tension in the 
dramatic text.

5) Replace in the TL the invariant core of the SL phrase in its two referential systems (the particular system of the text and the system of culture out of which the text has sprung) (2002, pp. 29-30).

Bassnett (2002) argues that it is immoral to contract or omit difficult expressions in translations. Bassnett also believes that the functional view must be adopted with regards to not only meaning but also style and form, and suggests that the translator cannot be the author of the SL text; rather, as the author of the TL text, the translator has a clear moral responsibility to the TL readers (30).

After the presentation of some important theoretical work above, it should be noted that the purpose of using Newmark's (1988) teaching methods is to help Taiwanese students understand the essence of translation, so that they will translate not by memory, but by the application of translation methods. The sophisticated techniques used in practice by translation specialists are of secondary importance in this course. Since students are in the initial stage of translation apprenticeship, it is suggested that teachers guide their students through practical examples with topics related to their daily life.

\section{The Importance of the Translator's Native Language}

Are Taiwanese students losing patience with reading and writing? It seems that they do not like to raise questions in class. When they are asked a question, they usually shrug and say, “I don't know". It seems that one would need to make a significant effort in rousing them to think and answer the question. When translating, it seems that their only desire is a prompt solution without an investment of careful thought. During exams, most students submit their papers immediately after completion. Very few students stay in the classroom to check their answers. One possible explanation for Taiwanese university students' low proficiency in Chinese reading and writing is that they spend an excessive amount of time on their cell phones or surfing the Internet each day. According to Ramos (2012), the frequent use of the Internet has made concentration a difficult task for Taiwanese students (247). Taiwanese students tend to surf the Internet not for reading articles but to watch films and communicate with their friends by using a lot of text-speak.

Newmark explains that student translators easily ignore the factor of the readership of the text:

The average text for translation tends to be for an educated, middle-class readership in an informal, not colloquial style. The most common variety of "marked" error in register among student translators tends to be "colloquial" and "intimate", e.g. use of phrases such as "more and more" for "increasingly" ... The other common error, use of formal or official register (e.g. "decease" for "death"), also shows signs of translationese. These tokens of language typify the student translators instead of the readership they are translating for; they may epitomize their degree of knowledge and interest in the subject and the appropriate culture, i.e. how motivated they are. All this will help you to decide on the degree of formality, generality (or specificity) and emotional tone you must express when you work on the text (1988, p. 13).

In the process of translation, students often neglect the importance of the knowledge of their native language. Students also often ignore cultural factors that would make their translation inappropriate. Student translators need to carefully consider the style of the language that they choose and take specific cultural factors into account. Bassnett (2002) suggests the importance of cultural elements in translation:

Language, thus, is the heart within the body of culture, and it is the interaction between the two that results in the continuation of life-energy. In the same way that the surgeon, operating on the heart, cannot neglect the body that surrounds it, so the translator treats the text in isolation from the culture at his peril (2002, p. 22).

Three interesting examples of student translations are provided as follows:

\subsection{Example 1}

"casa de té" en los monasterios budistas.

("tea house" in Buddhist monasteries).

$\lceil$ chashi 茶室」 (tea room) instead of 「chawu 茶屋」 (tea house).

"Chashi" is an inappropriate translation in the context of religion because of its cultural meaning. Fifty years ago in Taiwan, "chashi” can refer to a place that sells not only drinks, but also sexual services. Today, this kind of tea room can still be found in some countryside areas in Taiwan. 


\subsection{Example 2}

búsqueda del "espíritu".

(search of the "spirit").

$\lceil$ linghun 靈魂」(soul, ghost), 「jingshen 精神」 (spirit, vitality) instead of 「xinling 心靈」(heart and soul)

This term appeared in an article about the advantages of drinking green tea. In the phrase "search of the spirit", "xinling" is a more stylistic expression than the other two terms, "linghun" or "jingshen". In Taiwanese society, green tea is considered to be the top beverage choice for a high-quality, healthy life. Therefore, "xinling" would be the best choice for the translation of "espíritu" in this context.

According to Yang (2002), Mengzi is one of the most influential traditional Chinese philosophers after Confucius. He creates the important idea of "probing the goodness of nature through the goodness of heart". Explaining the use of the Chinese word "xin" 「心」 is a complicated issue. Please refer to J. Li, C. Ericsson, and M. Quennerstedt (2013) for further information:

The spirit in the Heart is the "soul"; this word delegates a common Chinese belief that "soul" resides in the Heart, [being] aware that the "transcendental" nature of xin cannot be measured; however this connotation should not be ignored (Li, Ericsson, \& Quennerstedt, 2013: p. 81).

\subsection{Example 3}

Ella no pudo revertir a su estado mortal.

(She could not revert to her mortal state).

「Ta sibuliao. 她死不了.」 (She is not going to die anyway). instead of 「Ta wufa huifu fanren zhi shen. 她 無法恢復凡人之身.」 (She could not revert to her mortal state).

In the old Chinese legend, Chang-O secretly swallowed the elixir of immortality that belonged to her archer husband Hou Yi, who had shot down nine suns in the ancient China. The translation "ta sibuliao" is in a colloquial style, and therefore would not be a suitable translation for the sentence "ella no pudo revertir a su estado mortal". The problem was that the student translator not only ignored the cultural elements of the legend but lacked vocabulary and was not able to think of other words with which to express this sentence. As a result, he selected the only word that he knew for this context, i.e. "to die" to represent the meaning of the whole sentence.

\subsection{Other Examples}

"ante" as "antes".

"ferry" as "ferrocarril".

"Europa" as "Egipto".

Further, misreading a single word would affect the structure of the complete sentence, resulting in an incomprehensible translation. For example, some students misread the word "ante" (miandui 面對; in front of) as “antes” (qian 前; before, previously); “ferry” (duchuan 渡船; ferry) as “ferrocarril” (tielu 鐵路; railroad); and “Europa” (ouzhou 歐洲; Europe) as “Egipto” (aiji 埃及; Egypt). As a teacher, I would be obliged to remind students to focus on the spelling of the word in order to avoid this type of mistakes.

\section{A Case Study}

This new model of teaching was inspired by Susan Bassnett's (2002) analysis of two advertisements, one for Scotch whisky and the other for Martini. In a British Sunday newspaper, the advertisement of whisky represented quality, purity, and social status, while the advertisement of Martini represented glamour, excitement, trendy living, and youth. However, in an Italian weekly news magazine advertising the same two products, Martini was represented as a traditional product and Scotch was represented as a new arrival, so that the images presented with the products were exactly the reverse of the British advertisement (Bassnett, 2002: p. 35). I adopted the idea that an advertisement for alcoholic beverages could have different cultural meanings in different cultures. Therefore, translating a Spanish advertisement of whisky into Chinese would be interesting and challenging for my students as a new model of teaching. For this assignment, students were required to translate a Spanish advertisement of whisky into Chinese during class (accessed 30 October 2014:

http://todowhisky.blogspot.com/ 2008/ 12/ publicidades- de- Whisky- chivas- regal- 12.html). The advertise- 
ment was an ideal teaching material for this assignment because of the length and the density of the writing style. Students were expected to employ all of the translation strategies that they had learned in class, including the eight translation methods proposed by Newmark (1988).

\subsection{A Task-Oriented Activity}

This advertisement translation exercise was a task-oriented activity. A method called Task-Based Language Teaching (TBLT) was originally created by Prabhu for teaching English as a second language in Bangalore in southern India (as quoted in Candlin, 1987). According to D. Li (2013), this approach has proven to be an effective method for the teaching of a foreign language:

The starting premise is that students learn more effectively when their minds are focused on the task they are trying to complete ... rather than on the language they are learning. In this learner-centred approach, the focus is placed on the learners, the process of learning, the reflective practice of learning, and the use of real world authentic tasks (Li, 2013: p. 7).

The process of this task-oriented approach consisted of six stages of teaching: pre-task, task, reporting, analysis, revision and reflection (2013, p. 8). The translation activity that I designed fulfilled the requirements of D. Li regarding the philosophy of TBLT:

1) The focus is on the learner as well as the teacher.

2) Learners construct knowledge of their own through experiencing and reflection.

3) The focus is more on learning than teaching; emphasis is placed on the development of learners' critical and problem-solving abilities.

4) Learners interact with peers as well as the teacher.

5) The teacher facilitates.

6) Students learn (construct knowledge) through interactions with peers, the teacher and the materials.

7) Students take responsibility for their learning, which leads to a heightened sense of ownership and strengthened motivation about learning.

8) Authentic (or simulated) materials and contexts are adopted in teaching.

(Li, 2013: p. 3).

It should be noted that as the teacher, I did not provide my own version of the translation to students. This was so that students would feel free to create their own work. However, students could consult me regarding the meaning of a word or an interpretation of the text if they had questions. The advantage was that students would not be influenced by the authorial other, i.e., the teacher. Further, students would need to solve the problems that arise in the process of translation by themselves.

The difference between the traditional translation instruction and a TBLT activity is illustrated as shown in Figure 1 and Figure 2.

\subsection{A Spanish Advertisement of Whisky}

In this case study, a Spanish advertisement of whisky was given to the students to read in class. Students were divided into four groups of four or five. After reading, students were given twenty minutes to translate this advertisement into Chinese. They were allowed to use a dictionary and discuss within their group. The purpose of this activity was to find an ideal translation of the advertisement, and to experience the application of translation methods and strategies.

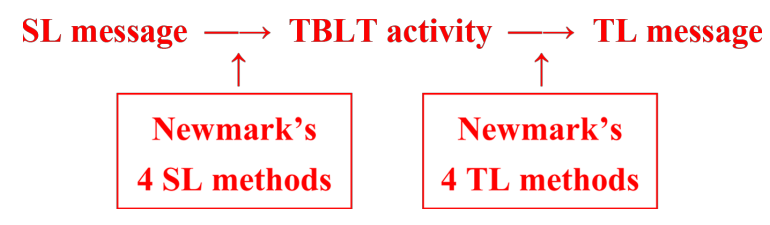

Figure 1. TBLT activity.

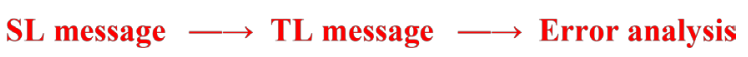

Figure 2. Traditional translation instruction. 


\title{
Whisky \\ Un sabor indescriptible y un placer sin igual es lo que, aquellos amantes de esta espirituosa bebida, desfrutamos cuando una tenue gota se desliza en nuestro paladar.
}

\author{
(An indescribable flavor and an unequalled pleasure is what we, \\ lovers of this spirit, enjoy \\ when a fine drop slides onto our palate.)
}

Students were asked to write down their translation on a worksheet. Then a representative elected by each group wrote the translations on the blackboard so that everyone could compare their own translations with those of their peers. Group 1 gave feedback to Group 2, and Group 2 gave feedback to Group 3, and so on. Each group was asked to give suggestions to their feedback group if there were words that they did not agree with. The result was four different versions of the translation from the four groups. After the comparison and feedback, each student gave two votes for their favourite translations among the four versions. Group 1 had the most votes and Group 3 had the second most votes. After class, students were asked to revise and resubmit their work in the following lesson. However, since most students were satisfied with their original work, there was not much difference between the original translation and the final version. The revision of the best and the second best translations are as follows:

1) “xiangshou yidi xiangchun/hua jin weilei/Hangjia ye nanyi-yanyu de/ weijue xiangyan!”.

(享受一滴香醇/滑進味蕾/行家也難以言喻/的/味覺饗宴!)

2) "lian pinchuzhe ye wufa xingrong de kougan/wuke-bini de yuyue tiaodou/rang women xiangshou ruhou de sihua xiangchun”.

(連品醇者也無法形容的口感/無可比擬的愉悅挑逗/讓我們享受入喉的絲滑香醇).

\subsection{Problem-Solving}

An advertisement is a type of professional writing that is different from ordinary writing, as it requires special attention and creative thought. An ordinary translation would not attract the eyes of a reader. Secondly, a word-toword or literal translation would not be suitable for this exercise because it would sound "absurd" and be considered "nonsense" in Chinese. Therefore, students must use methods such as semantic translation and communicative translation in order to find an ideal solution.

Surprisingly, a common word like "lover" (amante), which was used in this whisky advertisement, was the most challenging word to translate. This was because the literal translation of “lover”, “airen” 「愛人」, would sound vulgar in the context of drinking alcohol for Mandarin speakers. Therefore, none of the students chose this translation. They needed to find another word to make this translation more appealing. Students became aware of the need to be creative in order to find an ideal translation. A better translation of the word "lover", “aihaozhe”「愛好者」, would also not be an ideal translation because it is overused in advertisement. Although the translation “aihaozhe”「愛好者」 would be a better choice than “airen”「愛人」, it would not attract the attention of Chinese readers since this is often used for ordinary writing. We needed to find an ideal translation for the advertisement, which explained why the translation of Group 1 and Group 3 won the most votes. Group 1 used “hangjia” 「行家」, which means “expert”. Group 3 used the verb “tiaodou” 「挑逗」, which means “to seduce", instead of a noun for the translation of the word "lover".

In class, we agreed that "hangjia” 「行家」 and “tiaodou”「挑逗」 were both excellent choices for the translation of the word "lover". They presented ideal translation of advertisement writing for Chinese readers.

To summarize the translation choice of the word "lover" (amante) in Mandarin Chinese:

1) 行家 (hangjia): In English,"hangjia” means “an expert” or "a professional”, which is very positive. The use of these words would increase the appeal of the advertisement.

2) 挑逗 (tiaodou): “Tiaodou” (to seduce) has a sensual and romantic meaning for Chinese readers that would render it acceptable in the context of the Chinese culture.

3) 愛好者 (aihaozhe): This is a positive term. However, this is a common choice for translation and often appears in ordinary writing.

4) 愛人 (airen): “Airen” is a positive term when it is used singly or in a loving relationship with others. However, this term is never used in the context of drugs, alcohol, or any other vices or addictions. 


\section{Reflection}

During this experimental activity, students not only enjoyed the work of translation but also were aware of the importance of their Chinese language proficiency. In the later exercises and practice of the second semester, students were able to fulfill several requirements in order to search for an appropriate translation.

1) Learn to respect and follow the conventional transaltion of geographical terminology. For instance, in an article about the tourism in London, “la sede del Chelsea FC” is translated as “Quierxi zuqiu julebu”「切爾西足 球俱樂部」(Chelsea Football Club) and “el campo de cricket Lord’s” as “Luode banqiuchang”「羅德板球場」 (Lord's Cricket Ground).

2) Always look up a dictionary to find the correct meaning of the word that one is translating. For example, in an exercise of translating the poetry of Gloria Fuertes (1982), students were able to translate correctly two animals that appeared to be a rare term for Chinese readers, for example, “luo ma” 「駱馬」 (llama, vicuna in English) and 「洓奥」 “lai ao” (ñandú, rhea).

3) Be creative and confident in translating, especially in translating literary work such as poetry. At the end of the second semester, the students had a successful and pleasant experience of translating Octavio Paz's (1968) poem, “Shiren de mingyun” 「詩人的命運」 (Destino del poeta, The poet’s destiny). The focus on poetry translation will be investigated in my future study.

4) Learn slang words, expressions of praise, and dirty words. For example, students met this requirement in an exercise of sentiment analysis based on some specific topics about Internet culture (celebrities, movies, fashion, etc.).

5) Gain knowledge and practice of translating idioms that are found in children's books. Examples of such idioms are “hunao”「胡閙」 (hacer el indio, mischief in English) and “jinpilijie”「筋疲力竭」 (hacer polvos, to make one exhausted).

\section{Conclusion}

This case study of advertisement translation demonstrated that student translators were able to learn the importance of Chinese reading and writing in the process of translation. Further, they experienced the advantages of employing translation methods and translating strategies in order to find an ideal translation. Now, they pay attention to not only the form, but also the style of the language when translating. Most importantly, students learned to take cultural elements into consideration when making decisions in the translation process. The application of Newmark's eight translation methods is proved to be useful for student translators to solve translation problems. Students found not only confidence but also interest in the world of translation.

\section{References}

Bassnett, S. (2002). Translation Studies. London: Routledge.

Candlin, C. N. (1987). Towards Task-Based Learning. In C. Candlin, \& D. Murphy (Eds.), Lancaster Practical Papers in English Language Education, Volume 7: Language Learning Tasks (pp. 5-22). Englewood Cliffs, NJ: Prentice Hall.

Fuertes, G. (1982). El abecedario de Don Hilario. Illus. Helena Rosa. Valladolid: Miñón.

Li, D. (2013). Teaching Business Translation. The Interpreter and Translator Trainer, 7, 1-26.

Li, J., Ericsson, C. \& Quennerstedt, M. (2013). The Meaning of the Chinese Cultural Keyword Xin. Journal of Languages and Culture, 4, 75-89.

Munday, J. (2001). Introducing Translation Studies: Theories and Applications. Oxon: Routledge.

Neubert, A. (1967). Elemente einer allgemeinen Theorie der Translation. In Actes du Xe Congrès International des Linguistes, Bucarest II, 451-456.

Newmark, P. (1988). A Textbook of Translation. New York: Prentice Hall.

Nida, E. A. (1964). Toward a Science of Translation. Leiden: E. J. Brill.

Paz, O. (1968). Destino del poeta. In J. E. Englekirk, I. A. Leonard, J. T. Reid, \& J. A. Crow (Eds.), An Anthology of Spanish American Literature (Volume 2, p. 637). Englewood Cliffs, NJ: Prentice Hall.

Rabadán, R. (2005). Niveles de teorización en traducción: la transición entre teoría y práctica. In J. Y. Frías, \& A. Á. Lugris, (Eds.), Estudios sobre traducción: Teoría, didáctica, profesión (pp. 21-34). Vigo: Universidade de Vigo, Servizo de Publicacións.

Ramos, J. (2012). Los libros, el conocimiento y las pantallas (Reflexiones en torno a una probable batalla perdida). Encuen- 
tros en Catay, 26, 238-250.

Yang, H. (2002). The Logical Structure of Mencius’ Heart and Nature Theory. Journal of Nanchang University, 33, 6-11.

\section{Submit or recommend next manuscript to SCIRP and we will provide best service for you:}

Accepting pre-submission inquiries through Email, Facebook, LinkedIn, Twitter, etc.

A wide selection of journals (inclusive of 9 subjects, more than 200 journals)

Providing 24-hour high-quality service

User-friendly online submission system

Fair and swift peer-review system

Efficient typesetting and proofreading procedure

Display of the result of downloads and visits, as well as the number of cited articles

Maximum dissemination of your research work

Submit your manuscript at: http://papersubmission.scirp.org/ 